of knowing which: was the first to be affected. My observations do not lead me to believe in even primary tuberculosis of the larynx, and I am sure it would be difficult to find a case of primary tuberculosis of the tonsil. These remarks are in no wise a criticism but merely a plea for more accurate deductions.

Dunbar Roy, M.D., Atlanta, Ga.

\section{THE MEDICAL SECTION OF THE ADVISORY COMMISSION STILL BROADENING ITS FUNCTIONS}

To the Editor:-According to the lay press, the chairman of the Medical Section of the Advisory Commission of the Council of National Defense has rushed in with the members of his Volunteer Medical Service Corps to take a hand in, if not to take charge of. the outbreak of influenza in the country. In Illinois, and I suppose in other states, he telegraphs his state chairman to appoint a committee to attend to the situation, and forthwith a committee for that purpose springs into cxistence.

What does this action mean? There are only two obvious alswers. Either the usual constituted authorities for taking care of epidemics have failed, or the chairman of the Medical Section of the Advisory Commission is a sort of medical "all highest" in the United States, who is superior to all rcgular agencies and may step in when he sees fit.

We have for some time been accustomed to Colonel Martin's acting as though the Surgeon-Generals had to have. some one to take over a considerable part of their functions in medical military affairs. But this excursion into administering the public health of the nation indicates a broadening of his self-appointed functions. Why this further assumption of authority? Have the usual federal, state and municipal authorities proved unequal to their duties? It is their specific function to take care of such situations. They are paid for it, and they have men especially trained for it. Has there been a hreakdown in these agencies? Has Surgeon-General Blue gone in panic to Colonel Martin and appealed to him to help lim out of a situation that the Public Health Service of the Inited States cannot handle for the country at large? Have lhe state boards of health and the municipal boards of health come crying to him for help or proved futile, that these new bodies should suddenly step in to assume their task, or show them how to do it, or without invitation to offer to help them do it?

There is no such crisis in the administration of our public health affairs. Even if there were such a crisis, is there any rcason to believe that Colonel Martin is especially qualified to take care of the situation? $\mathrm{He}$ is not noted as a sanitarian, and the committees he appoints-if the Illinois committee is a sample-are not superior as sanitatians to our present regular officers. On his Illinois committee he interlards between busy practitioners the regular officers who crdinarily have charge of such woil...

And one wonders how these officers fecl about it. How do the Army and Navy and Public Health Service officers, the municipal and state health officers feel about sitting on these new committees suddenly formed to take over work that is usually up to them to do? I do not know how much open resentment there may be, but $I$ think it would be hard to find a better illustration of mischievous meddling with other men's duties than this, or of actions tending more to confusion in the administration of public affairs and more to the lowering of the spirit of public officials.

If the newspaper publicity given to this action of Colonel Martin's-and the publicity was as great as usual and probably just as expensive-carries any implication to the public mind, it is that the usual authorities for looking after epidemics are unequal to their duty of taking care of this epidemic, and we must have a "god from the machine" come in to do it for them. This act, in fact, like Colonel Martin's attempt to force on the profession his Volunteer Medical Service Corps, is the act of one who apparently feels that he is a sort of national medical Pooh-Bah. The Medical Departments of the Army and Nav, the Office of the Provost Marshal-General, the Public Health Service, the offices of administration of state and local public health affairsapparently all of these came within the scope of his functions -at least until the Provost Marshal-General announced last week that "membership in Volunteer Medical Service Corps is not service in the military establishment and does not therefore affect in any way the status of registrants before the Selective Service Boards."

It is a mischievous situation that Colonel Martin is forcing on us. The profession is confused by his actions. He has, I should estimate, sent probably a million letters to the profession under government frank about matters more or less connected with the war. Physicians do not know how authoritative these communications are. He has a way of writing-as he did in the case of his Volunteer Medical Service Corps, telling men to sign-as if he were clothed with federal authority to command, when, as a matter of fact, he is exploiting his own desires and plans; and physicians often do not know how much his communications represent federal authority and how much his own personal activities and views.

I am sure I sense the attitude of the profession when I say that its members are zealous in the highest degree to do all they can now for the public good, to know the wishes of the government in order to try to comply with them; that they accept instantly and without reservation-accept as ordersthe communications of the Surgeon-Generals and the Provost Marshal-General. But-speaking now only for the profession of Chicago which I believe I know-a great many of them would prefer to get their orders and their instructions from the Surgeon-Generals of the Army, Navy, the U. S. Public Health Service and the Provost Marshal-General, who surely are competent to issue them.

William Allen Pusey, M.D., President of the Chicago Medical Society.

\section{AN AUTHOR PROTESTS}

To the Editor:-May I not thank you for the complimentary review of my book "Diet and Health with Key to the Calories" and at the same time take issue with your reviewer on the following points? He says: "By its title it assumes to be a parody on the guide of a well known religiomedical cult. This, however, appears only slightly in the text in the form of a few of the side headings." I fear he has missed the point that $I$ have used their terminology throughout and my chapter of testimonies is a model of their literature. Furthermore, the reviewer says that the humor is a little forced. Again I differ with him. It is a great deal more than a little forced. It is very much forced, in fact almost forcibly forced. It has been killed, assassinated, annihilated, and dragged in most any place and any time. I did it purposely. Who reads an ordinary book on dietetics? Even a doctor will read mine!

Lulu Hunt Peters, Los Angeles.

Notification of Ophthalmia Neonatorum.-According to the Hedical Officer, the local government board for Scotland has issued regulations under the public health act of 1897 for the compulsory notification of ophthalmia neonatorum in Scotland, dating from Nov. 1, 1918. Although no direct arrangement is made by the local government board for treating and following up these cases, it is pointed out that this follow-up work might properly come under the duties assigned to health visitors under the regulations relating to maternity service and child welfare, and that the child welfare grant is available for this purpose. It is therefore hoped by the board that the local authorities will avail themselves of this resource and see that all notified cases of ophthalmia neonatorum receive immediate treatment. The Royal Commission on Venereal Diseases reported that probably 25 per cent. of all cases of blindness are due to ophthalmia neonatorum, and that probably 50 per cent. of all blindness is due to the venereal diseases, syphilis being a prolific cause. 